\title{
Reactions of Gluten with Anhydride Derivatives
}

\author{
A. H. Gheath, N. M. Al-Farsi and N. M. Alarafi ${ }^{*}$ \\ Chemistry Department, Faculty of Science, Benghazi University, Benghazi, Libya
}

\begin{abstract}
Gluten was extracted from wheat flour followed by chemical modification of groups such as the free $\varepsilon$-amino group of lysine in proteins with acid anhydrides such as, maleic anhydride (2), Diacetyl-d-tartaric anhydride (3), 7-oxa bicyclo [2.2.1] hept-5-ene- cis -2, 3- dicarboxylic anhydride (4), 9, 10-dihydroanthracene9,10- $\alpha, \beta$-succinic anhydride (5) and Triphenylphosphoranylidenesuccinic Anhydride (6). Attachment of such side groups will alter repulsive or attractive forces among polypeptides to cause certain structural rearrangement, which in turn may cause changes in functional properties of modified gluten. Also different properties were determined comparing with original gluten
\end{abstract}

Keywords: gluten, anhydride, $\varepsilon$-amino group.

\section{Introduction}

Native wheat gluten can be fractionated into two different classes of proteins gliadin and glutenin. Hydrated gliadin is an extensible syrupy material, whereas hydrated glutenin is a cohesive and rubbery mass. Both fractions together make wheat gluten "vital" and "alive" unlike other natural plant proteins. Hydrated gluten exerts its ability to form a visco-elastic mass ${ }^{[1]}$.

The effective utilization of proteins entails matching a wide variety of functional and nutritional characteristics to the complex needs of manufactured food products. This is often difficult because many native proteins posses limited functionality, therefore, there is technical need for development of methodology to manipulate plant proteins and endow them with desirable functional characteristics ${ }^{[2]}$.

Chemical modification of groups such as the free $\varepsilon$-amino group of lysine in proteins with acid anhydride has resulted in improved functional properties without formation of undesirable products ${ }^{[3]}$. Ideally, Chemical modification of food proteins should enhance functional properties without impairing their nutritive value $^{[4]}$, therefore amino acylating reagents which are structurally similar to succinic anhydride and form an acid labile amide bond with the lysine $\varepsilon$-amino group of proteins, e.g., citraconic ${ }^{[5]}$ and maleic ${ }^{[6]}$ anhydrides have potential applications because of the relative ease of deacylating the lysine derivatives under mildly acidic conditions.

Materials

\section{Materials And Methods}

Wheat flour was commercially available and anhydride derivatives were prepared in laboratory in Benghazi University.

\section{Preparation of wheat gluten}

About $15 \mathrm{ml}$ water was added to $25 \mathrm{~g}$ of wheat flour in a bowl, worked up in to a dough avoiding adherence to the container. The dough was left to stand for an hour, then kneaded gently in a stream of cold tap water, allowing the washings to pass through a fine sieve until all starch and soluble matter were removed.

It was tested for the removal of starch by squeezing the ball of gluten and immerge into a beaker of cold water until clear solution is obtained. Any bits of gluten caught by the sieve were gathered up and added to the ball of gluten. The gluten was left to stand in cold water for an hour; then was vied with the hands to squeeze out as much water as possible. The obtained ball was placed in a glass watch and weighed as "moist gluten". This was then dried at $100{ }^{\circ} \mathrm{C}$ for 24 hours or to a constant weight. This was then weighed and reported as "dry gluten") ${ }^{\text {[7] }}$.

Weight of moist gluten $=156.7 \mathrm{~g}$.

Weight of dry gluten $=47.20 \mathrm{~g}$.

The Nitrogen content was determined in dry gluten by micro-kjeldahl ${ }^{[8]}$ nitrogen analysis $($ Protein $=$ $\mathrm{N} \%$ X $5.7=75 \%)$.

\section{Preparation modified wheat gluten}

Modification was performed by using solid anhydride derivatives (1,2,3,4,5 and 6) as follows: wheat gluten $2 \mathrm{~g}$ protein was added to $250 \mathrm{ml}$ of phosphate buffer, $\mathrm{pH} \mathrm{8.5}$. solid anhydride derivatives, in $0.5 \mathrm{~g}$, increments were added to a total of $2 \mathrm{~g}$ with stirring over a period of $40 \mathrm{~min} .1: 2,1: 3$ (w/w protein/ anhydride) 
with stirring over the same period. During modification the $\mathrm{pH}$ was maintained at $\mathrm{pH} 8.5$ with $3.5 \mathrm{~N} \mathrm{NaOH}$. Modification was completed; the solutions were exhaustively dialyzed against distilled water ( $4{ }^{\circ} \mathrm{C}$ for 48 hour) to remove impurities and excess reagents. The modified proteins were dried (at $\left.40{ }^{\circ} \mathrm{C}\right)$ until complete dryness. Sample of protein was treated similarly without the addition of anhydride served as control ${ }^{[9]}$.

\section{Properties of protein}

Protein solubility: Modified wheat gluten and original protein were dispersed in water $(0.1 \% \mathrm{w} / \mathrm{v})$ and $\mathrm{pH}$ was adjusted in the range 3-8 with either $\mathrm{HCl}$ or $\mathrm{NaOH}$ solutions. The resulting solutions were centrifuged at 3000 RTM for 15 min. the supernatant was filtered through What man No.1 filter paper, protein content was determined in the supernatant by the method of Biuret ${ }^{[10]}$ with Egg albumin as standard. Protein solubility was expressed as the percentage of total concentration ${ }^{[11]}$.

\section{Protein solubility $=\frac{\text { Amount of soluble protein }}{\text { Amount of total protein }} \mathrm{X100}$}

Emulsifying capacity: Aqueous protein dispersions or solutions containing $0.1,0.2(\mathrm{w} / \mathrm{v})$ proteins were prepared and brought to complete solubility by raising the $\mathrm{pH}$ to 9.5 in case of native protein and $\mathrm{pH} 7.5$ for modified proteins by the addition of $0.2 \mathrm{M} \mathrm{NaOH}$ while stirring for 1 hour. Protein suspensions or solutions (100 $\mathrm{ml}$ ) were mixed in a ken wood food mixed at highest speed while corn oil, containing 40mg/1L of Sudan III dye as indicator, was added continuously with a constant rate. The end- point of emulsification capacity was determined by carefully observing the change in emulsion viscosity and separation of the continuous and dispersed phases at the time of emulsion collapse (break-point) and also the change in color of the oil phase from pink to orange. The volume of oil added when the break-point was reached was used to express the emulsifying capacity (E.C), calculated as $\mathrm{ml}$ oil/gram protein ${ }^{[12]}$.

Foaming properties: Aqueous protein dispersion containing 1-3\% (w/v) protein was prepared and adjusted to $\mathrm{pH} 9.5$ for original protein and $\mathrm{pH} 7.5$ for the modified protein by addition of $0.3 \mathrm{M} \mathrm{NaOH}$ while stirring for 15 min. the protein dispersions $(50 \mathrm{ml})$ were then whipped in a food mixer at the highest speed for $5 \mathrm{~min}$. immediately after whipping the foam was transferred to a $100 \mathrm{ml}$ graduated cylinder and foam volume measured.

\section{Foam overrun $=\frac{\text { Volume after whipping }- \text { Volum before whipping }}{X 100}$ \\ volum before whipping \\ Foam stability was determining measuring the decrease in foam volume with time ${ }^{[12]}$.}

\section{Results And Discussion}

Reactivity of amino group toward the electrophilic carbon lead the researchers to use this property to mask the amino group either to protect it from reagent or to block the amino group against definite property, for this reason number of anhydrides were designed to react with gluten in order to alter some properties of the protein.

The reaction of wheat gluten with anhydride derivatives can be explained by the nucleophilic addition of free $\varepsilon$-amino group of lysine in protein to the electrophilic carbonyl group, leading to anhydride ring opening and forming the negative charge hydrophilic groups on the protein molecules, this step was illustrated in following mechanism (schem.1).

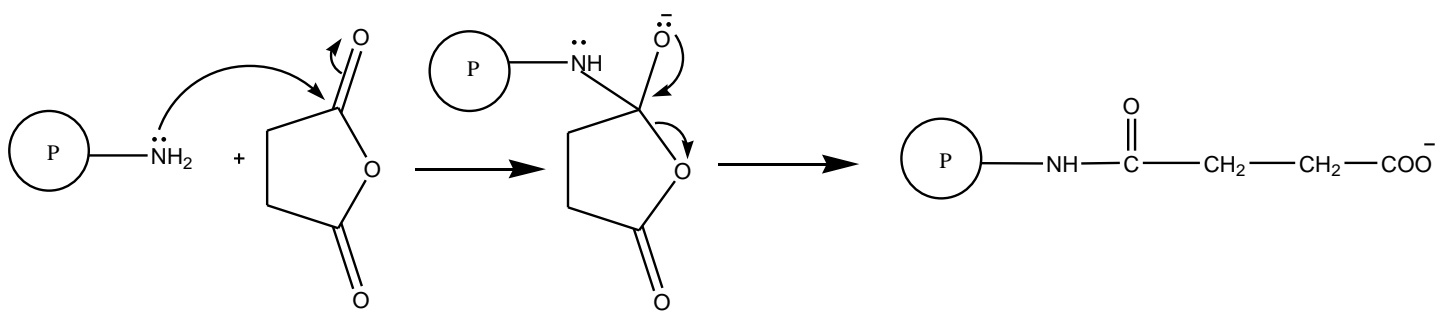

Sechem.1. The action of amino group with an succinic anhydride (1).

On the other hand compounds were reacted in the same manner with wheat gluten, such as, maleic anhydride (2), Diacetyl-d-tartaric anhydride (3), 7-oxa bicyclo [2.2.1] hept-5-ene- cis -2, 3- dicarboxylic 
anhydride (4), 9, 10-dihydroanthracene-9,10- $\alpha, \quad \beta$-succinic $\quad$ anhydride $\quad(5) \quad$ and Triphenylphosphoranylidenesuccinic Anhydride (6).

Attachment of such side groups will alter repulsive or attractive forces among polypeptides to cause certain structural rearrangement, which in turn may cause changes in functional properties of modified gluten.

The chosen anhydrides were taken in consideration their polarity and shape of the molecule because those two properties play a role in reaction with protein, as the polarity of the added anhydride increase should the solubility increase by the formation of hydrogen bond between the formed carboxylate ion and the medium in which the protein is present as well as increasing of the negative charge on the protein molecule, for these reasons diacetyl-d- tartaric anhydride (3) was suspected to enable the best solubility of the protein first by masking the amino group and Second by the high polarity of the added molecule. Also the size of the anhydride gives it the advantage to penetrate through the protein molecule.<smiles>CC(=O)O[C@H]1C(=O)OC(=O)[C@@H]1OC(C)=O</smiles>

3<smiles>CC(=O)O[C@@H](C(=O)[O-])[C@@H](OC(C)=O)C(=O)N[Co]</smiles>

III ( a , b)

Changing the properties and shape of molecule i.e. increasing the nonpolar part and/or making the molecule more hindered to come in between the protein molecule had faced our assumption by altering the properties of the protein in opposite way to diacetyl-d- tartaric anhydride (3).<smiles>O=C1CC(=P(c2ccccc2)(c2ccccc2)c2ccccc2)C(=O)O1</smiles><smiles>N#CONC(=O)C(CC(=O)O)=P(c1ccccc1)(c1ccccc1)c1ccccc1</smiles>

VI (a, b)

Addition of the bicyclic anhydrides with hindered structures but with different polarity showed different results in the protein properties.<smiles>O=C1OC(=O)C2C3C=CC=CC3C3CC(c4ccccc43)C12</smiles><smiles>O=C1OC(=O)C2C3C=CC(O3)C12</smiles><smiles></smiles>

$\mathbf{V}(\mathbf{a}, \mathbf{b})$<smiles>N#[W]NC(=O)C1C2C=CC(O2)C1C(=O)O</smiles>

IV(a,b) 
Succinic anhydride (1) and maleic anhydride (2) were also used in this investigation first of their use by many researchers in order to compare the results obtained by the proposed anhydrides ${ }^{[6-13]}$.

\section{pH- solubility curves of modified gluten}

The solubility profile of native and modified derivatives of gluten protein is presented in (tables 1-2), the maximum solubility for $\mathrm{nGP}$ was at $\mathrm{pH} 3$ and a much lower solubility at $\mathrm{pH} 5-7$ which corresponds to its isoelectric point (IEP), whereas derivatives had minimum solubility at PH 3-4.5 and maximum solubility at pH 7 (fig.1).

\begin{tabular}{|l|l|}
\hline \multicolumn{2}{|l|}{ Control gluten } \\
\hline $\mathrm{pH}$ & Nitrogen solubility\% \\
\hline 3.0 & 79 \\
\hline 4.0 & 26 \\
\hline 5.0 & 22 \\
\hline 6.0 & 20 \\
\hline 7.0 & 20 \\
\hline 8.0 & 33 \\
\hline
\end{tabular}

Table 1. Nitrogen solubility profile for control gluten.

\begin{tabular}{|l|l|l|l|}
\hline \multicolumn{2}{|l|}{ III $_{\mathbf{a}}$ Ratio 1:2 } & \multicolumn{2}{l|}{$\mathbf{I I}_{\mathbf{b}}$ Ratio 1:3 } \\
\hline $\mathrm{pH}$ & Nitrogen solubility\% & $\mathrm{pH}$ & Nitrogen solubility\% \\
\hline 3.0 & 65 & 3.0 & 44 \\
\hline 4.0 & 61 & 4.0 & 35 \\
\hline 5.0 & 47 & 5.0 & 25 \\
\hline 6.0 & 77 & 6.0 & 38 \\
\hline 7.0 & 81 & 7.0 & 50 \\
\hline 8.0 & 87 & 8.0 & 58 \\
\hline
\end{tabular}

Table 2. Nitrogen solubility profile for sample (III).

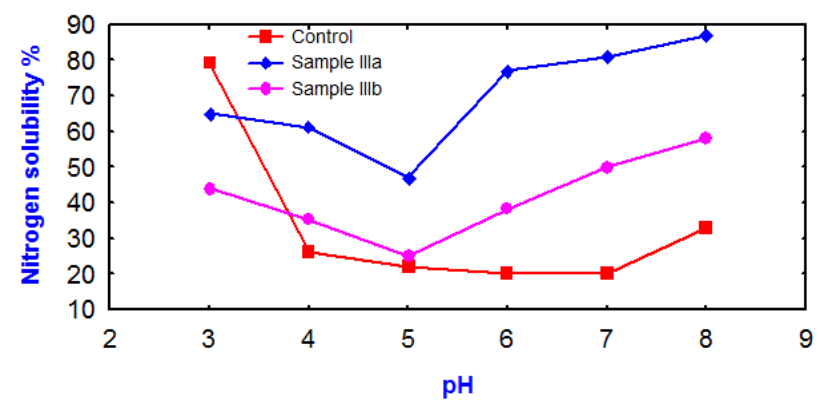

Figure 1.Nitrogen solubility profile for sample (III).

After modification (sample III), the cationic amino groups on proteins are converted to anionic residues. The result is an increase in net negative charge, which causes an increase in aqueous solubility. Enhanced solubility after modification could be explained based on the structure of modified proteins. Modification involves the replacement of short-range attractive forces in the native molecule with short range repulsive ones and this result in subsequent unfolding of polypeptide chains. Electrostatic attractions between neighboring ammonium and carboxyl, which reduced protein solubility by protein-protein interactions in native gluten protein have been limited in succinylated protein derivatives. This is as a result of introduction of electrostatic repulsion between the added carboxyl groups and the neighboring native carboxyl groups, which produced less protein-protein interactions and more protein-water interactions. Since net negative charge is directly related to the extent of amino modification, hence the improvement in aqueous solubility was directly proportional to the extent of modification. The same result was also obtained with samples IV anhydride, but the solubility in different orders.

\begin{tabular}{|l|l|l|l|}
\hline \multicolumn{2}{|l|}{$\mathbf{I V}_{\mathbf{a}}$ Ratio 1:2 } & \multicolumn{2}{l|}{$\mathbf{I V}_{\mathbf{b}}$ Ratio 1:3 } \\
\hline $\mathrm{pH}$ & Nitrogen solubility\% & $\mathrm{pH}$ & Nitrogen solubility\% \\
\hline 3.0 & 50 & 3.0 & 71 \\
\hline 4.0 & 47 & 4.0 & 62 \\
\hline 5.0 & 47 & 5.0 & 56 \\
\hline 6.0 & 53 & 6.0 & 70 \\
\hline 7.0 & 61 & 7.0 & 75 \\
\hline 8.0 & 65 & 8.0 & 80 \\
\hline
\end{tabular}

Table 3.Nitrogen solubility profile for adduct (IV). 


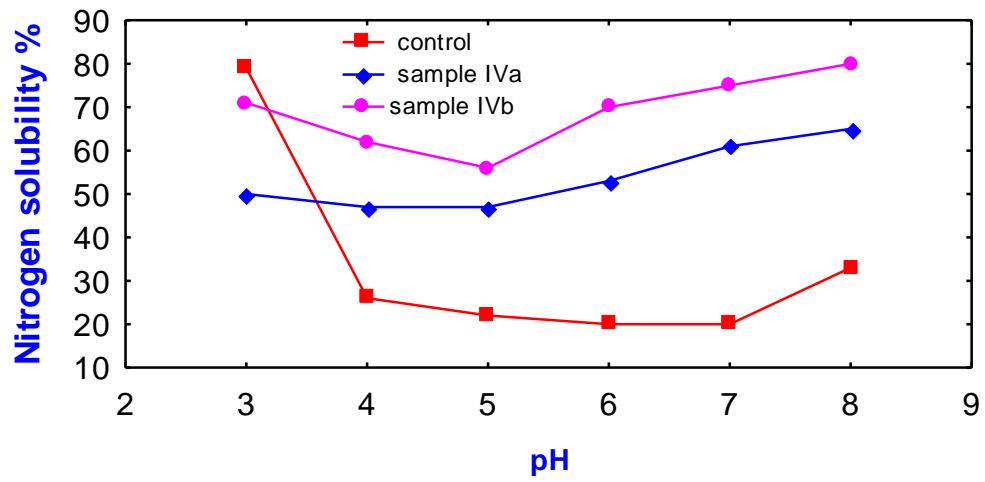

Figure 2.Nitrogen solubility profile for sample (IV).

But the result differ with samples (V, VI) (tables 4-5), at pH 5-7 there was no significant difference in solubility between samples (V) and (VI) but both samples (V, VI) were less soluble than control gluten, the lack of solubility of modified gluten is likely due to bulky size of non polar group (fig.3-4).

\begin{tabular}{|l|l|l|l|}
\hline \multicolumn{2}{|l|}{$\mathbf{V}_{\mathbf{a}}$ Ratio 1:3 } & \multicolumn{2}{l|}{$\mathbf{V}_{\mathbf{b}}$ Ratio 1:6 } \\
\hline $\mathrm{pH}$ & Nitrogen solubility\% & $\mathrm{pH}$ & Nitrogen solubility\% \\
\hline 3.0 & 14 & 3.0 & 13 \\
\hline 4.0 & 14 & 4.0 & 10 \\
\hline 5.0 & 13 & 5.0 & 10 \\
\hline 6.0 & 13 & 6.0 & 14 \\
\hline 7.0 & 13 & 7.0 & 15 \\
\hline 8.0 & 16 & 8.0 & 16 \\
\hline
\end{tabular}

Table 4 . Nitrogen solubility profile for adduct $(\mathrm{V})$.

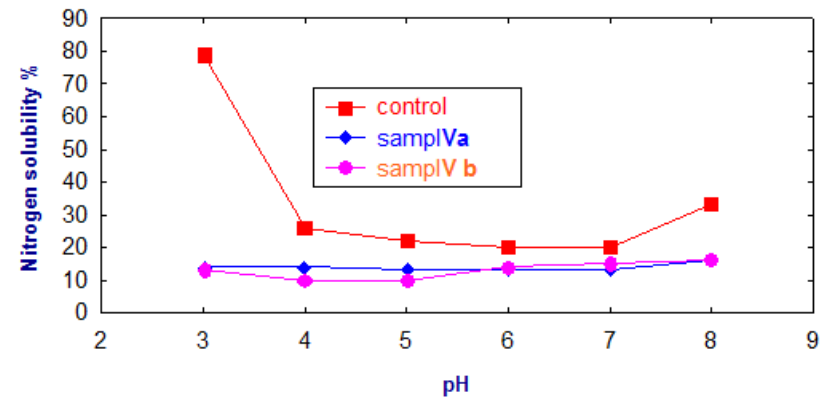

Figure3. Nitrogen solubility profile for sample (V).

\begin{tabular}{|l|l|l|l|}
\hline \multicolumn{2}{|l|}{$\mathbf{V I}_{\mathbf{a}}$ Ratio 1:2 } & \multicolumn{2}{l|}{$\mathbf{V I}_{\mathbf{b}}$ Ratio 1:3 } \\
\hline $\mathrm{pH}$ & Nitrogen solubility\% & $\mathrm{pH}$ & Nitrogen solubility\% \\
\hline 3.0 & 13 & 3.0 & 16 \\
\hline 4.0 & 12 & 4.0 & 14 \\
\hline 5.0 & 12 & 5.0 & 13 \\
\hline 6.0 & 15 & 6.0 & 14 \\
\hline 7.0 & 17 & 7.0 & 17 \\
\hline 8.0 & 18 & 8.0 & 22 \\
\hline
\end{tabular}

Table 5. Nitrogen solubility profile for sample (VI).

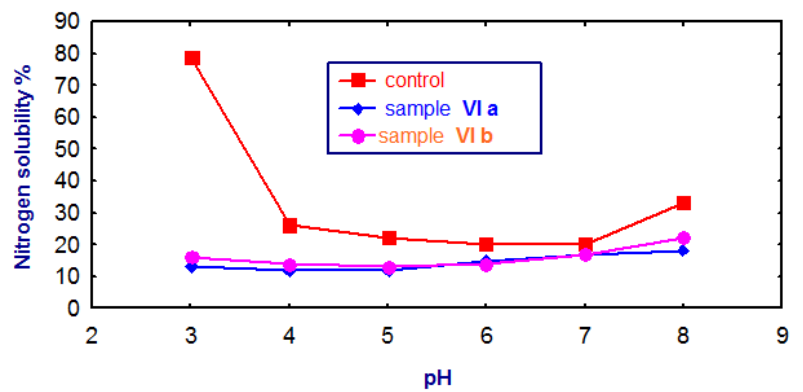

Figure 4.Nitrogen solubility profile for sample (VI). 


\section{Emulsifying capacity of modified gluten}

The emulsifying capacity ( $0.1 \%$ protein) of non modified wheat gluten at $\mathrm{pH} 9.5$ and of modified wheat gluten at $\mathrm{pH} 7.5$ is shown in (table 6).

\begin{tabular}{|l|l|}
\hline Sample & Emulsifying capacity ml.oil/g. protein \\
\hline Control gluten & 162 \\
\hline $\mathbf{I I I}_{\mathbf{a}}$ & 34 \\
\hline $\mathbf{I I I}_{\mathbf{b}}$ & 50 \\
\hline $\mathbf{I V}_{\mathbf{a}}$ & 90 \\
\hline $\mathbf{I V}_{\mathbf{b}}$ & 70 \\
\hline $\mathbf{V}_{\mathbf{a}}$ & 140 \\
\hline $\mathbf{V}_{\mathbf{b}}$ & 125 \\
\hline $\mathbf{V I}_{\mathbf{a}}$ & 120 \\
\hline $\mathbf{V I}_{\mathbf{b}}$ & 105 \\
\hline
\end{tabular}

Table 6. Effect of modification on emulsifying capacity of control Gluten (at pH 9.5) and modified gluten (at $\mathrm{pH} 7.5)$.

Original wheat gluten showed a higher emulsifying capacity at $\mathrm{pH} 9.5$ than of modified wheat gluten at $\mathrm{pH}$ 7.5. This might be due to the influence of $\mathrm{pH}$ on protein solubility. The result indicates that lipophilic tendency reduced after modification. Modification by anhydrides increased the net negative charge and decreased hydrophilic of nGP, resulting in a decrease in oil absorption. It can also be noticed that there was no high change in the emulsifying capacity between the modified gluten samples with different rates of modification.

However, it can be noticed from (fig. 1 to 2 ) that original protein was non soluble at $\mathrm{pH} 7.5$, while modified proteins was soluble at this $\mathrm{pH}$. At the oil-water interface, the protein orients lipophilic residues to the oil phase and hydrophilic residues to the aqueous phase, thus reducing surface tension at the interface. Modification enhanced exposure of lipophilic and hydrophilic residues and this facilitated improved EA.This means that the modification increased the emulsification effect at this $\mathrm{pH}$ of modified protein.

However, carrying out the emulsification test on the completely soluble part of both original gluten (at $\mathrm{pH}$ 9.5) and modified gluten (at $\mathrm{pH}$ 7.5) showed that the emulsification capacity of the modified proteins was lower than the original one. In other words, after excluding the solubility factor, the emulsification capacity of the modified proteins was inferior that the hydrophilic groups attached to protein turns it is more hydrophilic at the neutral $\mathrm{pH}$ range. Hence, it will be more soluble in water layer and the emulsification system is likely to be affected. But it can be noticed from (table 6) the modified gluten (V, VI) has high emulsion capacity than other samples because effect non polar groups.

\section{Foaming properties of modified gluten}

The effect of protein concentration on the overrun of original gluten at $\mathrm{pH} 9.5$ and modified gluten at pH 7.5 is shown in (table7). A direct relationship was observed between increase in concentration of the protein concentrate and increase in foam capacity. In addition, progressive increase in level of modification also increased the foam capacity of the protein concentrates.

It can seen that increasing protein concentration from 1 to $3 \%$ led to an increase in foam overrun in both original and modified gluten.

\begin{tabular}{|l|l|l|l|}
\hline \multirow{2}{*}{ samples } & \multicolumn{3}{|l|}{ Foam overrun \% } \\
\cline { 2 - 4 } & \multicolumn{4}{|l|}{ Protein concentration \% } \\
\hline & $\mathbf{1 \%}$ & $\mathbf{2 \%}$ & $\mathbf{3 \%}$ \\
\hline Control gluten & 20 & 30 & 40 \\
\hline $\mathbf{I I I}_{\mathbf{a}}$ & 50 & 60 & 70 \\
\hline $\mathbf{I I I}_{\mathbf{b}}$ & 40 & 50 & 50 \\
\hline $\mathbf{I V}_{\mathbf{a}}$ & 40 & 40 & 50 \\
\hline $\mathbf{I V}_{\mathbf{b}}$ & 50 & 50 & 60 \\
\hline $\mathbf{V}_{\mathbf{a}}$ & 60 & 80 & 94 \\
\hline $\mathbf{V}_{\mathbf{b}}$ & 100 & 100 & 100 \\
\hline $\mathbf{V I}_{\mathbf{a}}$ & 20 & 30 & 30 \\
\hline $\mathbf{V I}_{\mathbf{b}}$ & 20 & 30 & 40 \\
\hline
\end{tabular}

Table 7.Effect of protein concentration on the foam overrun of original and modified wheat gluten.

Increase in concentration of protein solution enhanced foam capacity. This is possibly due to availability of more protein molecules as the concentration of protein concentrate increased in the aqueous dispersion.

Modification can cause unfolding of the protein by the increased net negative charge of modified proteins would especially promote protein-water interaction, which facilitates improved foaming capacity. 
Due to an increase in the net charge of the protein molecules, this weakens hydrophobic interactions and increases protein flexibility. This allowed them to spread to the air water interface more quickly thus encapsulating air particles and increasing foam formation ${ }^{[3]}$.

The foam stability of both native and modified gluten as measured by foam collapse over time was the same figure. The similarity of foam stability of these two proteins refers to their solubility and their good interfacial properties at the $\mathrm{pH}$ values used in the determination (fig. 5-10).

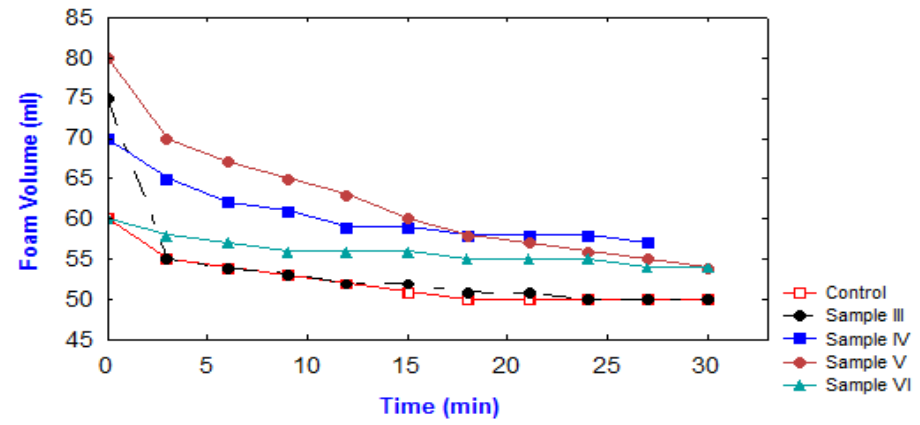

Figure 5.foam stability as measured by foam volume over time (min) for sample 1:2 (1\%).

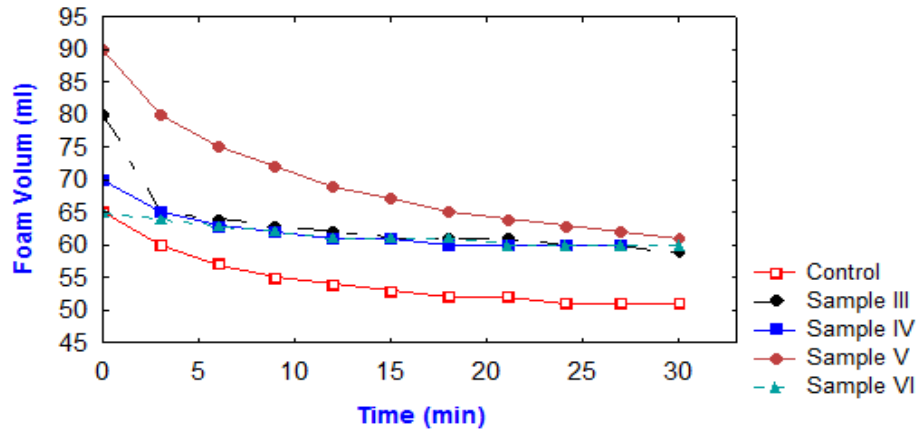

Figure 6.foam stability as measured by foam volume over time (min) for sample 1:2 (2\%).

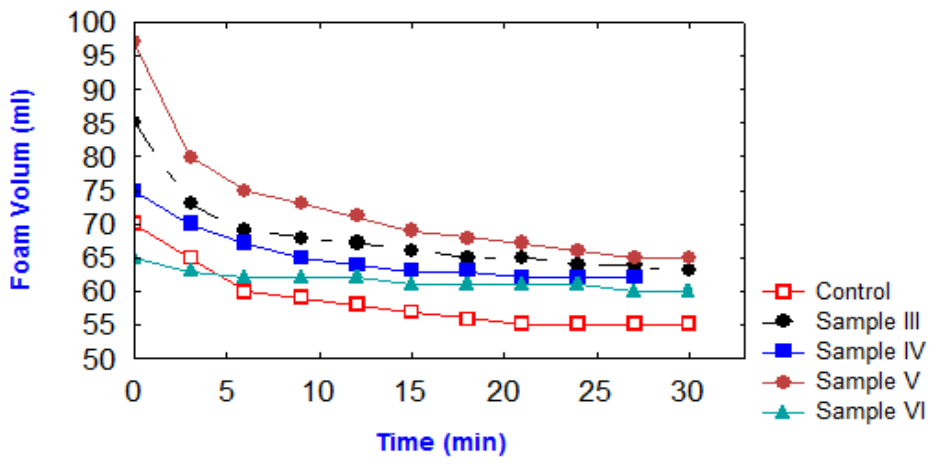

Figure7.foam stability as measured by foam volume over time (min) for sample 1:2 (3\%).

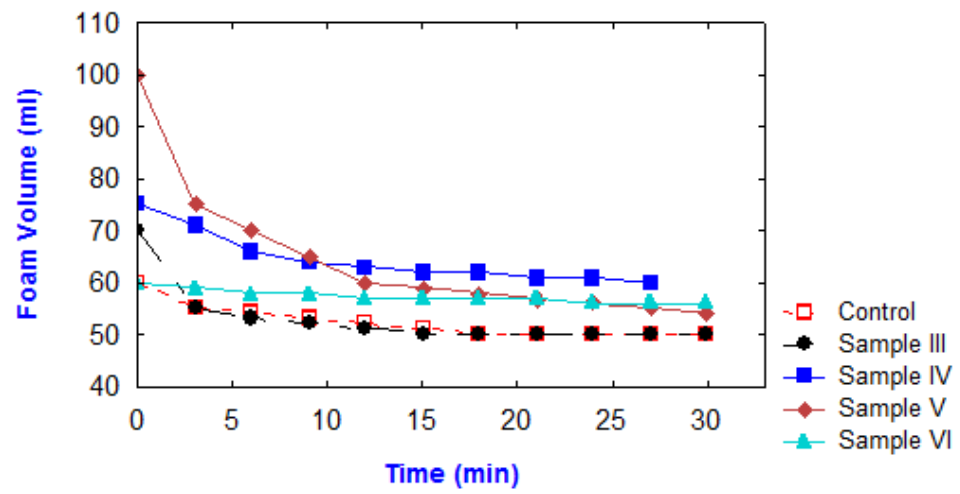

Figure 8.foam stability as measured by foam volume over time (min) for sample 1:3 (1\%). 


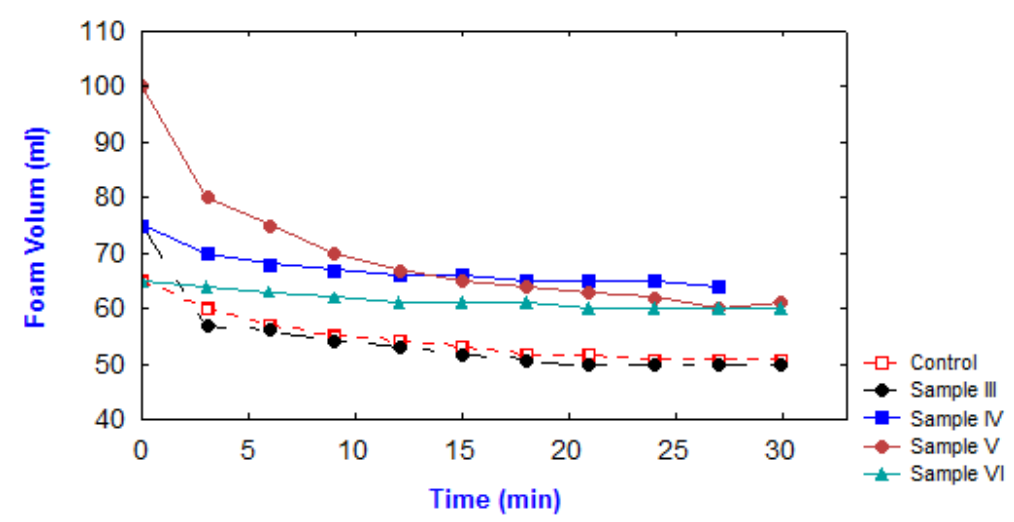

Figure 9.foam stability as measured by foam volume over time ( $\mathrm{min})$ for sample $1: 3(2 \%)$

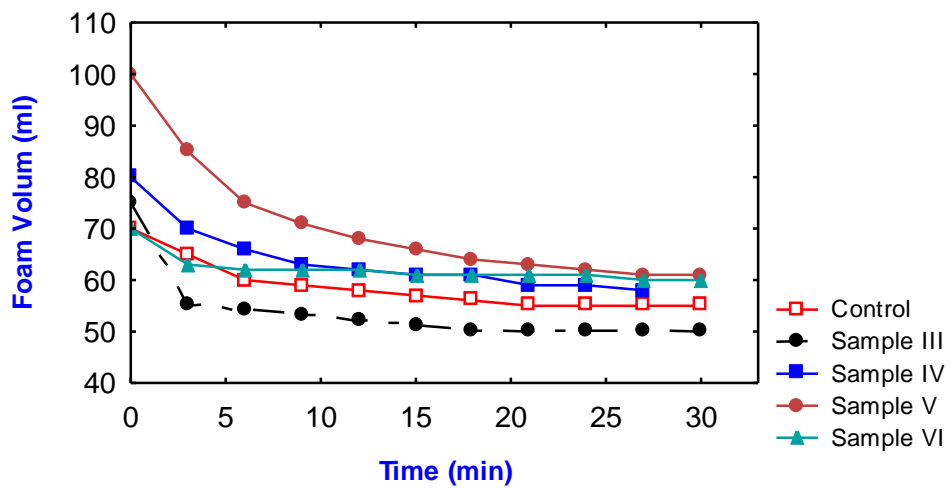

Figure10.foam stability as measured by foam volume over time (min) for sample 1:3 (3\%)

\section{Conclusion}

Attachment of such side groups will alter repulsive or attractive forces among polypeptides to cause certain structural rearrangement, which in turn cause changes in functional properties of modified gluten. Also different properties were determined comparing with original gluten showed a clear different properties between gluten and the modified protein. Modification can cause unfolding of the protein by the increased net negative charge of modified proteins would especially promote protein-water interaction, which facilitates improved foaming capacity.

\section{References}

[1]. Kalin, N. F., J. Am. Oil Chem. Soc. 56, 477-479, 1979.

[2]. Dua, S. and Mahajan, A., J. Agric. Food Chem. 44, 706-710,1996.

[3]. Kinsella, J.E., and Shetty, K.J., Am. Chem. Soc. Symp. Ser. 92, 37-63,1979.

[4]. Feeney, R. E., and Whitaker, J.R. chemical and Enzymatic modification of plant protein , New Protein Foods.,181-200, Academic \& Publishers Inc.,New York, 1985.

[5]. Dixon, H.B. F., Perham, R.N., Biochem. J. 109, 312, 1968.

[6]. Butler, P. J. G., Harris, J. L., Hartley, B. S., Leberman, R., Biochem. J. 112, 679, 1969.

[7]. A.A.C.C. Cereal laboratory Methods, $8^{\text {th }}$ edition, Am. Chem, Soc. Cereal Chemists, Inc. Minnesota ,1962.

[8]. Bradstreet, R.B. The Kjeldhal Method for Organic Ntrogen, Academic Prees, New York and London ,1965.

[9]. Hoagland, P.D. J Dairy Sci. 49, 783-787, 1966.

[10]. Gornall, A.G., Bardawill,C. J., and David, M.M. J.Biol. Chem.177-751, 1949

[11]. Betschart, A.A. J. Food Sci. , 39, 1110 , 1974.

[12]. Fayed, H.H., PH.D. Thesis, Facully of Agric. Zagazic University, 1987.

[13]. Baber. K.J and Warthesen. J.J., J. Agric. Food Chem. 30, 930-934,1982. 